\title{
Wilting effect on fermentation characteristics and nutritive value of mountain permanent meadow grass silage
}

\author{
Gerolamo Xiccato $^{a *}$, Roberto Parigi Bini ${ }^{a}$, Alberto Carazzolo ${ }^{b}$, \\ Angela Trocino ${ }^{\text {a, Maria Elena Cossu }}{ }^{\mathrm{a}}$
}

\author{
"Dipartimento di Scienze Zootecniche, Università di Padova, Agripolis, \\ 35020 Legnaro (Padova), Italy \\ ${ }^{b}$ Ente di Sviluppo Agricolo del Veneto, Via Uruguay, 45, \\ 35127 Camin (Padova), Italy
}

(Received 26 January 1998; accepted 24 April 1998)

\begin{abstract}
Grass from a pre-alpine permanent meadow located in the Cansiglio Highland (north Italy) was ensiled immediately after harvesting (T00), and after $5 \mathrm{~h}$ (T05) and $26 \mathrm{~h}$ (T26) of wilting. Two types of experimental silos were used to assess the chemical characteristics and the evolution of fermentation processes in pre-wilted silages: $500 \mathrm{~L}$ capacity silos (S500), opened after 6 months, and $2 \mathrm{~L}$ mini-silos (S002), opened at different times after ensiling $(0,12,24,48,96$ and $192 \mathrm{~h}$ ). The forages ensiled in $\mathrm{S} 500$ silos were also fed to sheep in order to assess their digestibility and palatability. Dry matter (DM) concentration of fresh grass increased with wilting from 303 to $568 \mathrm{~g} / \mathrm{kg}$, while the concentration of other nutrients was scarcely affected by pre-wilting. Fermentation characteristics were significantly modified by wilting with an increase in $\mathrm{pH}$ (from 3.82 to 4.33 ) and a concurrent reduction in fermentation activity. All the fermentation end-products significantly decreased in the wilted silages: lactic acid decreased from 51.6 to $13.1 \mathrm{~g} / \mathrm{kg}$ DM. Wilting did not affect the extent of fermentation losses. The fermentation processes in the short term were influenced by wilting with a slower development taking place in the wilted silages. The dry matter digestibility and the nutritive values of wilted silages were higher than those of unwilted silages (dDM: 0.52 in T00 to 0.58 in T26 silages), while voluntary intake of DM was not modified by wilting. (๑ Elsevier / Inra)
\end{abstract}

\section{mountain meadow grass / wilting / ensiling / nutritive value}

Résumé - Effet du préfanage sur les caractéristiques de la fermentation et la valeur alimentaire d'une prairie permanente de montagne. Trois tonnes d'herbe provenant d'une prairie sur le haut plateau du Cansiglio (Belluno, Italie du Nord) ont été ensilées immédiatement après la récolte (T00), et après $5 \mathrm{~h}$ (T05) ou $26 \mathrm{~h}$ de préfanage en plein air en juillet. Deux types de silos expérimentaux ont

* Correspondence and reprints

Tel.: (39) 49 8272639; fax: (39) 49 8272669; e-mail: xiccato@agripolis.unipd.it 
été utilisés pour évaluer respectivement les caractéristiques chimiques et l'évolution des processus de fermentation dans les ensilages préfanés : 12 silos ayant une capacité de $500 \mathrm{~L}$ (S500) (quatre silos par lot), ouverts après 6 mois, et 54 mini-silos ayant une capacité de $2 \mathrm{~L}$, ouverts à différents moments après l'ensilage $(0,12,24,48,96$ et $192 \mathrm{~h})$ (trois mini-silos par lot pour chaque temps). Les fourrages ensilés dans les silos $\mathrm{S} 500$ ont été donnés à 15 moutons (cinq par lot) afin d'en mesurer la digestibilité, la consommation volontaire et la valeur nutritive. La teneur en matière sèche (MS) de l'herbe fraîche a augmenté de 303 (T00) à $568 \mathrm{~g} \cdot \mathrm{kg}^{-1}$ (T26) avec le préfanage mais les autres éléments nutritifs ont été peu modifiés. Les caractéristiques de fermentation ont été influencées significativement par le préfanage : le pH a augmenté (de 3,82 à 4,33) et l'activité de fermentation a été réduite ; l'acide lactique a diminué de façon significative de 51,6 (T00) à 13,1 $\mathrm{g} \cdot \mathrm{kg}^{-1} \mathrm{MS}$ (T26) ainsi que les concentrations en acide acétique et en azote ammoniacal. Le préfanage n'a pas affecté les pertes pendant les 6 mois d'ensilage, tandis que l'évolution des processus de fermentation durant $162 \mathrm{~h}$ après l'ensilage a été plus lente dans les ensilages préfanés. La digestibilité et la valeur alimentaire des ensilages préfanés ont été plus élevées que celles de l'ensilage non traité (dMS : de 0,52 dans l'ensilage T00 à 0,58 dans l'ensilage T26). En revanche, l'ingestion volontaire n'a pas été modifiée par le préfanage. En conclusion, le préfanage peut améliorer la qualité de conservation de l'ensilage, ainsi que sa valeur alimentaire. Cette dernière observation paraît être en contradiction avec plusieurs études qui ont montré une réduction de la qualité nutritionnelle des ensilages préfanés. (C Elsevier / Inra)

\section{prairie permanente de montagne / préfanage / ensilage / valeur nutritive}

\section{INTRODUCTION}

Forage production in hill and mountain areas is limited by the low quality of grass produced, mostly as hay. Many factors influence hay quality, in particular meteorological conditions during grass harvesting and field wilting, and the slow growth of the grass in spring. These conditions result in the grass being of low nutritional quality and are responsible for high losses in both the quantity and quality of hay.

The pre-alpine area $(800-1500 \mathrm{~m}$ above sea level) of north-eastern Italy is characterized by high annual rainfall $(1500-2000 \mathrm{~mm})$, with abundant rain in April and May and frequent showers in summer. This situation permits only one harvest of grass to be field cured in the period from mid-July to midAugust, and sun drying often requires 4 days or more because of frequent showers, especially in the afternoon.

The ensiling of grass can represent a valid alternative to hay-making due to the better nutritional and galactopoietic properties of grass silages. The principal drawback to the ensiling of grass is its moisture content, which is nearly always too high to guarantee the correct development of fermentation processes. The wilting of fresh herbage prior to ensiling can be helpful in this respect.

During the ensiling of pre-wilted forages, the lower moisture content reduces microbial activity, protein degradation, and fermentation losses, and prevents effluent losses $[12,15,21]$.

The experimental results on the effects of pre-wilting on the nutritive value and livestock performance of silage are rather contradictory. Gordon [6] and Thomas and Thomas [21] reported that pre-wilted silages showed lower apparent digestibilities than unwilted silages, even though the voluntary intake was generally stimulated following wilting. On the contrary, Yan et al. [28] observed higher digestibility when animals were fed pre-wilted silages. As reviewed by Gordon [6], animal performances usually appear to be affected negatively by pre-wilting, whereas other authors describe positive or unaffected results $[5,8,19]$.

The aim of the present research was therefore to evaluate the effect of different prewilting periods on the fermentation processes, preservation characteristics, and nutritive value of silages obtained from permanent meadow grass in pre-alpine areas. 


\section{MATERIALS AND METHODS}

\subsection{Herbage harvesting and silo preparation}

The permanent meadow, located in a farm owned by E.S.A.V. (Agriculture Development Agency of Veneto Region) in the pre-alpine area (Vallorch, Cansiglio Highland, $1000 \mathrm{~m}$ above sea level) was cut at full blooming. The meadow was characterized by a high content of grass species (about 60\%, in particular Phleum pratense and Festuca rubra), a limited presence of legume species (about $10 \%$, mainly Trifolium pratense) and a wide range of other families (Cruciferae, Compositae, Polygonaceae, etc.).

Three tons of herbage were harvested during the second week of July. The grass was cut between 09.30 to $10.00 \mathrm{a} . \mathrm{m}$. using a horizontal rotary mower from an area of about $2000 \mathrm{~m}^{2}$. The grass was lifted from the field in alternate rows at three times using a green crop cart with a front pick-up loader: one third of the herbage was loaded immediately (treatment T00); one third was left in the field for $5 \mathrm{~h}$ without tedding (treatment T05); one third was left to wilt until 5.30 p.m., then windrowed for the night; the windrow was spread the next day at $09.30 \mathrm{a} . \mathrm{m}$. and the grass was picked up at 11.30 a.m. after an overall pre-wilting period of $26 \mathrm{~h}$ (T26). Before cutting and during wilting, weather conditions were stable and sunny, with high temperature and low humidity.

Immediately after harvesting, the herbage was moved to a roofed shelter where it was chopped using an electric straw cutter. The chopped material was then ensiled in 12 experimental silos (four silos for each pre-wilting treatment). These silos had 500 L capacity (S500), a hermetic cover, and a valve at the bottom to permit the recovery of effluents. These silos were stored in a shed and opened 6 months later.

At the same time, 54 mini-silos of $2 \mathrm{~L}$ capacity, consisting of glass jars for food preserves equipped with hermetic covers, were filled (S002). These silos, stored in the same shed of the S500, were opened at different times after ensiling: $0,12,24,48,96$ and $192 \mathrm{~h}$ (three minisilos $\times$ three wilting treatments $\times$ three ensiling times).

More detailed information on ensiling technique and experimental silo typology has been provided in previous papers $[25,26]$.

\subsection{Digestibility trial and voluntary intake}

Silages stored in the S500 silos were fed consecutively to 15 ewes of Finnic or Lamon breed (five animals per pre-wilting treatment) during a digestibility and voluntary intake trial carried out following the methodology suggested by the Associazione Scientifica di Produzione Animale [1].

Each group of ewes was fed with silage ( $40 \mathrm{~g}$ $\mathrm{DM} /$ day $/ \mathrm{kg} \mathrm{LW}^{0.75}$ of silage) and trace mineralvitamin supplement $(50 \mathrm{~g} /$ day) during a 21 -day preliminary period. The same diet was fed throughout the 7-day collection period, during which faeces were collected daily for each individual animal ( $10 \%$ of total weight) and stored at $-18^{\circ} \mathrm{C}$. At the end of the digestibility trial, voluntary intake was measured for 7 days following an adaptation period of 4 days in which the animals were fed ad libitum. This adaptation period was sufficient to reach a constant voluntary intake in the following 7 days.

At the end of the digestibility trial, two samples $(200 \mathrm{~mL})$ of rumen liquor were taken from each ewe by an esophagus probe connected with a vacuum pump: the first sampling immediately after feeding and the second $3 \mathrm{~h}$ later.

\subsection{Sample collection and analytical procedures}

The fresh material was sampled when the experimental silos were prepared, taking nine samples for each S500 silo. When the experimental silos were opened, nine samples per S500 silo and 1 sample per $\mathrm{S} 002$ silo were immediately taken. After DM determination, the samples taken from the S500 silos were bulked to provide three samples for further analyses (three samples per silo).

Fresh grass, silages, faeces and rumen liquor were analyzed following the methods previously described [26].

The DM content and the chemical composition of the silages were corrected according to their concentrations of organic acids, alcohols and ammonia- $\mathrm{N}$ as suggested by Dulphy and Demarquilly [4].

The apparent digestibility coefficients of the various nutrients and energy in the experimental diets were calculated on the basis of the ingestaexcreta balance and the chemical composition 
of foods and faeces. The nutritive value of the silages was estimated from the proximate chemical composition and the in vivo apparent digestibility coefficients as described by Vermorel [24].

The experimental results were submitted to analyses of variance using the least squares mean method and the LSMLMW program [9]. For the statistical analyses of the fermentation characteristics, ensiling losses, and in vivo digestibility coefficients, a linear model that considered wilting period (W) as a principal effect was utilized. In addition to this effect, the analyses of the progress of fermentation characteristics in the $\mathrm{S} 002$ silos also included the 'time after ensiling' effect $(T)$ and the interaction $(W \times T)$ effect.

\section{RESULTS}

\subsection{Chemical composition of fresh and ensiled forages}

The stage of growth of herbage at cutting was quite advanced, as demonstrated by the high DM concentration $(303 \mathrm{~g} / \mathrm{kg}$ ) and the fairly high level of NDF $(669 \mathrm{~g} / \mathrm{kg}$ DM) of the fresh material (treatment T00) (table I). The degree of lignification of grass was still moderate, but the protein concentration was low ( $84 \mathrm{~g} / \mathrm{kg} \mathrm{DM})$, as a consequence of the late harvesting of the mea- dow and the type of grass species present.

Owing to the good weather conditions during wilting, DM rose to 472 and $568 \mathrm{~g} / \mathrm{kg}$ in T05 and T26 grasses, respectively. A reduction in the protein concentration was observed as the pre-wilting period increased (84 to $76 \mathrm{~g} / \mathrm{kg} \mathrm{DM}$ ). The NDF concentration increased in the T26 forage, but this change was not confirmed by similar variations in other cell wall constituents.

On the whole, the chemical composition of the silages is consistent with that of fresh herbage at ensiling (table I). The ether extract concentration proved to be higher in all the silages when compared to fresh products, due to the accumulation of fermentation metabolites included in the etherextract fraction [22] and decreased with the pre-wilting period.

\subsection{Fermentation characteristics}

Fermentation characteristics of silages stored for 6 months in $\mathrm{S} 500$ silos were generally good (table $I I$ ).

As the herbage DM increased with wilting period, the final $\mathrm{pH}$ reached higher levels ( 3.82 vs. 4.04 vs. 4.33 , in the T00, T05 and

Table I. Chemical composition of fresh grass and silages (means \pm S.D.).

\begin{tabular}{lccccccc}
\hline & \multicolumn{3}{c}{ Fresh grass } & & \multicolumn{3}{c}{ Silages } \\
\cline { 2 - 3 } \cline { 6 - 8 } Wilting (h) & T00 & T05 & T26 & & T00 & T05 & T26 \\
& 0 & 5 & 26 & & 0 & 5 & 26 \\
\hline No. of samples & 12 & 12 & 12 & 12 & 12 & 12 \\
DM(g/kg) & $303 \pm 14$ & $472 \pm 26$ & $568 \pm 33$ & $297 \pm 11$ & $459 \pm 18$ & $569 \pm 19$ \\
Crude protein (g/kg DM) & $84 \pm 4$ & $79 \pm 9$ & $76 \pm 6$ & $83 \pm 5$ & $78 \pm 7$ & $76 \pm 3$ \\
Ether extract (g/kg DM) & $24 \pm 4$ & $20 \pm 2$ & $21 \pm 2$ & $38 \pm 6$ & $29 \pm 5$ & $25 \pm 4$ \\
Ash (g/kg DM) & $49 \pm 5$ & $48 \pm 5$ & $44 \pm 2$ & $50 \pm 4$ & $48 \pm 3$ & $45 \pm 1$ \\
NDF (g/kg DM) & $669 \pm 13$ & $677 \pm 16$ & $685 \pm 20$ & $622 \pm 20$ & $639 \pm 11$ & $647 \pm 10$ \\
ADF (g/kg DM) & $395 \pm 9$ & $396 \pm 8$ & $386 \pm 8$ & $387 \pm 17$ & $389 \pm 15$ & $394 \pm 12$ \\
ADL (g/kg DM) & $64 \pm 4$ & $65 \pm 5$ & $57 \pm 3$ & $56 \pm 7$ & $52 \pm 10$ & $55 \pm 8$ \\
\hline
\end{tabular}

I Silages stored in $500 \mathrm{~L}$ capacity silos ( 5500 ). 
Table II. Effect of length of wilting period on fermentation characteristics of the silages in the 500 L capacity silos ( $\mathrm{S} 500$ ).

\begin{tabular}{|c|c|c|c|c|c|c|}
\hline \multirow[b]{2}{*}{ Wilting (h) } & \multicolumn{4}{|c|}{ Silages } & \multicolumn{2}{|c|}{ Significancel } \\
\hline & $\begin{array}{c}\text { T00 } \\
0\end{array}$ & $\begin{array}{c}\text { T05 } \\
5\end{array}$ & $\begin{array}{c}\text { T26 } \\
26\end{array}$ & s.e.d. & $L$ & $Q$ \\
\hline No. of silos & 4 & 4 & 4 & & & \\
\hline $\mathrm{pH}$ & 3.82 & 4.04 & 4.33 & 0.04 & $* * *$ & \\
\hline Ammonia $N(\mathrm{~g} / \mathrm{kg}$ total $\mathrm{N})$ & 61.2 & 48.2 & 37.2 & 3.4 & $* * *$ & \\
\hline Lactic acid (g/kg DM) & 51.6 & 26.5 & 13.1 & 2.1 & $* * *$ & $* *$ \\
\hline Acetic acid (g/kg DM) & 21.6 & 16.3 & 7.9 & 1.5 & $* * *$ & \\
\hline Propionic acid (g/kg DM) & 1.1 & 0.4 & 0.5 & 0.5 & & \\
\hline Butyric acid (g/kg DM) & 0.9 & 0.1 & 0.1 & 0.4 & * & \\
\hline Ethanol (g/kg DM) & 9.4 & 5.3 & 3.6 & 0.4 & $* * *$ & $* * *$ \\
\hline Mannitol (g/kg DM) & 30.6 & 28.4 & 23.0 & 2.1 & $* * *$ & \\
\hline Glucose + fructose $(\mathrm{g} / \mathrm{kg} \mathrm{DM})$ & 23.6 & 30.4 & 39.1 & 3.7 & $* * *$ & \\
\hline Homolactic index ${ }^{2}$ & 1.73 & 1.28 & 1.06 & 0.10 & $* * *$ & \\
\hline Flieg score ${ }^{3}$ & 86 & 90 & 90 & & & \\
\hline
\end{tabular}

' $L$, linear component of variance; $Q$, quadratic component.

${ }^{2}$ Lactic acid/(acetic acid + ethanol) ratio.

${ }^{3}$ Flieg score as modified by Vanbelle and Bertin [23].

T26 silages, respectively), while organic acid production, especially that of lactic acid, decreased $(P<0.01)$. The activity of proteolytic micro-flora and the consequent ammonia- $\mathrm{N}$ concentration decreased (from 61.2 to $37.2 \mathrm{~g} / \mathrm{kg}$ of total $\mathrm{N}, P<0.001$ ), along with both butyric and propionic fermentation. The production of ethanol was similarly reduced by wilting, while the production of the most prevalent alcohol, i.e., mannitol, was less affected.

In T00 silage, homolactic fermentation appeared to be predominant in comparison with the heterolactic fermentation: the homolactic index, i.e., the ratio between lactic acid and the sum of acetic acid and ethanol [26], was 1.73, whereas it decreased to 1.28 and 1.06 in T05 and T26 silages, respectively.

The Flieg score, as modified by Vanbelle and Bertin [23], was always 'very good' regardless of the wilting treatment.

\subsection{Ensiling losses}

No effluent losses were observed during the storage of any of the silages.

The higher fermentation losses observed in the T00 and T05 silages than in T26 silage (table III) suggested a trend, but statistical analysis did not reveal any significant differences among treatments. Only ether extract gain was significantly reduced in wilted silages because of the decrease in fermentation activity and as outlined earlier the inclusion of organic acids in the ether extract fraction. On average, hemicellulose was more degraded than other chemical constituents (0.14 to 0.17$)$.

Wilting modified the density of herbage within the silos: from $0.45 \mathrm{~g} / \mathrm{cm}^{3}$ in $\mathrm{T} 00$ silage to $0.28 \mathrm{~g} / \mathrm{cm}^{3}$ in T26 silage. This was brought about by the length of chopping and limiting the compression at ensiling. 
Table III. Effect of length of wilting period on density (fresh basis) and ensiling losses of the silages in the $500 \mathrm{~L}$ capacity silos (S500).

\begin{tabular}{|c|c|c|c|c|c|c|}
\hline \multirow[b]{2}{*}{ Wilting (h) } & \multicolumn{4}{|c|}{ Silages } & \multicolumn{2}{|c|}{ Significance ${ }^{l}$} \\
\hline & $\begin{array}{c}\mathrm{T} 00 \\
0\end{array}$ & $\begin{array}{c}\text { T05 } \\
5\end{array}$ & $\begin{array}{c}\text { T26 } \\
26\end{array}$ & s.e.d. & $L$ & $Q$ \\
\hline No. of silos & 4 & 4 & 4 & & & \\
\hline Density $\left(\mathrm{g} / \mathrm{cm}^{3}\right)$ & 0.45 & 0.33 & 0.28 & 0.01 & $* * *$ & $* * *$ \\
\hline \multicolumn{7}{|l|}{ Ensiling losses } \\
\hline Dry matter & 0.030 & 0.037 & 0.012 & 0.029 & & \\
\hline Organic matter & 0.031 & 0.037 & 0.012 & 0.030 & & \\
\hline Crude protein & 0.045 & 0.049 & 0.011 & 0.023 & & \\
\hline Ether extract & -0.558 & -0.354 & -0.172 & 0.138 & $*$ & \\
\hline NDF & 0.099 & 0.092 & 0.066 & 0.030 & & \\
\hline Hemicellulose & 0.169 & 0.144 & 0.163 & 0.041 & & \\
\hline
\end{tabular}

' $L$, Linear component of variance; $Q$, quadratic component.

\subsection{Evolution of fermentation process over time}

The fermentation characteristics of the silages stored in the experimental mini-silos (S002) during 8 days after ensiling are listed in table $I V$.

Given that no significant interaction between the effect of the wilting period (W) and hours after ensiling $(\mathrm{T})$ was observed, the general evolution of the fermentation processes can be described by the mean values of the principal effects.

Wilting period significantly affected $(P<0.001)$ all fermentation characteristics (mean values of the six opening times), except for the production of butyric acid $(<0.01 \mathrm{~g} / \mathrm{kg})$ and propionic acids. The fermentation patterns observed only a few days after ensiling clearly reflected the final characteristics measured in the mature silages 6 months later ( 5500 silos). The increase in DM concentration due to wilting resulted in a higher $\mathrm{pH}$ and a lower concentration of fermentation end-products in comparison with unwilted silage, while glucose and fructose were less fermented.

The effect of hours after ensiling was even greater than that of wilting, and led to a sharp variation in $\mathrm{pH}$ and end-product concentrations (mean values of three wilting treatments). Fermentation activity was weak in the first 12 to $24 \mathrm{~h}$, and particularly intense during the following $24 \mathrm{~h}$ : in the second day, $\mathrm{pH}$ decreased quickly (4.64 on average), while organic acids rapidly increased (figure $l a, b, c)$. Both lactic acid and acetic acid reached their maximum rate of increase after around $48 \mathrm{~h}$, with a clear slowdown after $96 \mathrm{~h}$.

The production of ethanol and mannitol followed different trends: a rather high concentration of ethanol was achieved within $48 \mathrm{~h}$ after ensiling, while mannitol production was appreciable only after $48 \mathrm{~h}$ (figure $l d, e$ ).

Proteolysis was apparent from the second day of ensiling (table $I V$, figure $1 f$ ), as were both lactic and acetic production. 


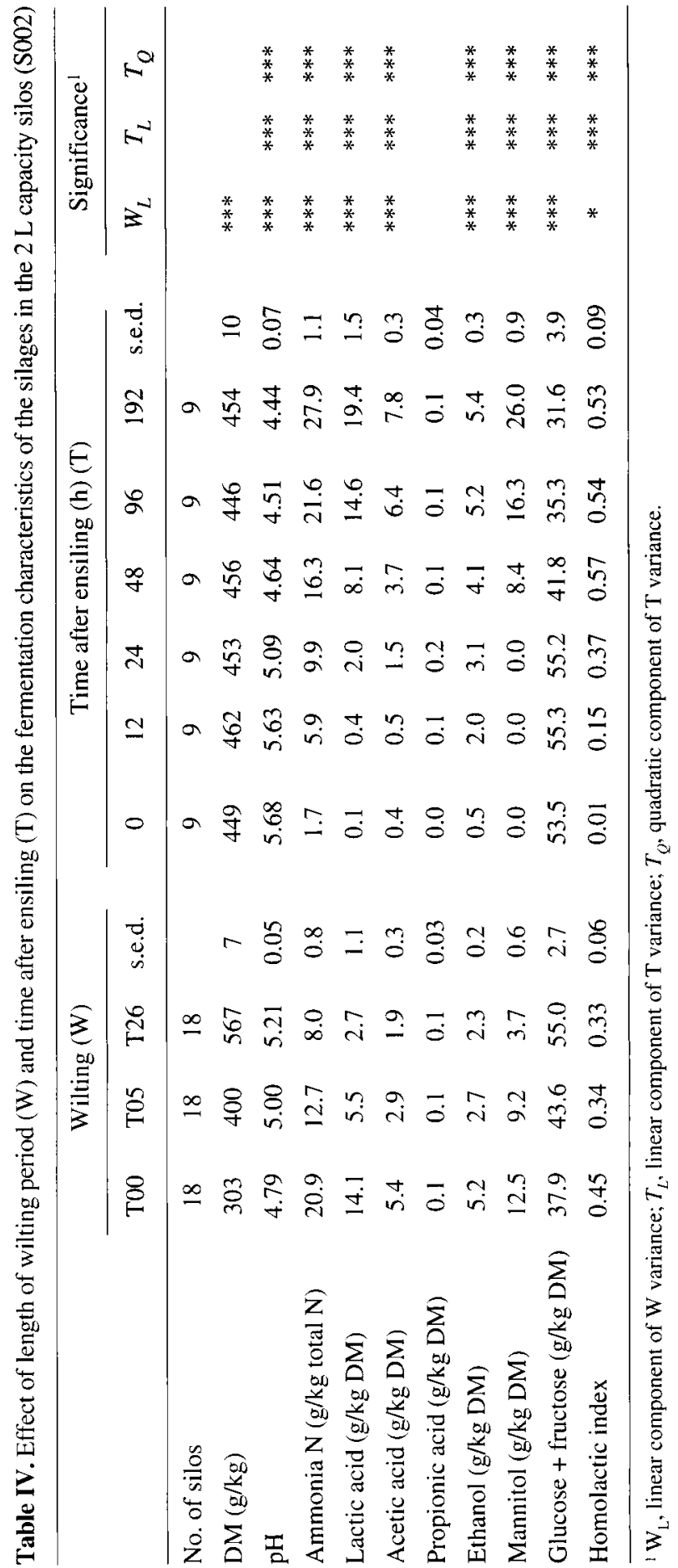




\subsection{Digestibility, nutritive value and rumen fluid composition}

Digestibility coefficients and nutritive value of the three silages are shown in table $V$.

a)

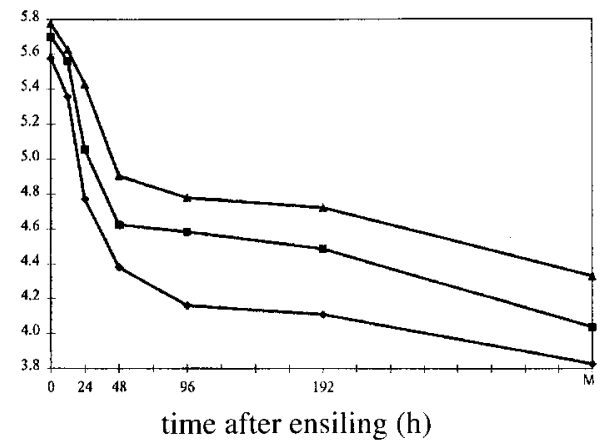

c)

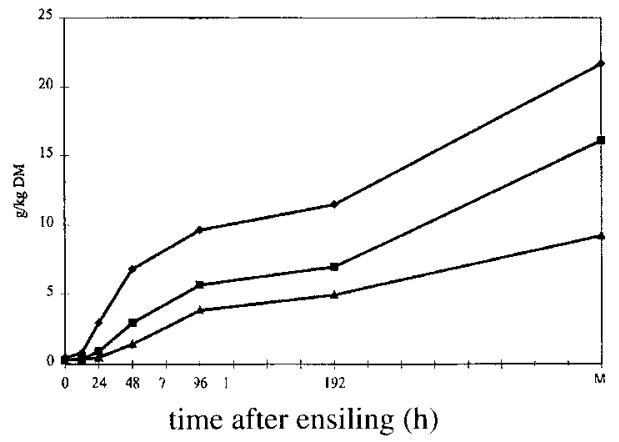

e)

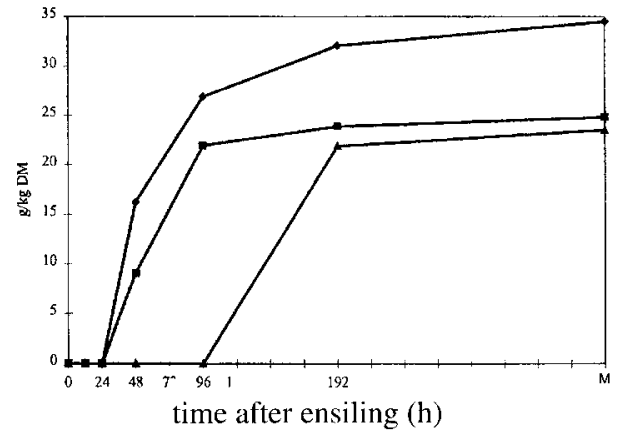

The unwilted silage had low apparent digestibilities of DM, energy and crude protein, whereas the digestibility of cellulose was higher. As a consequence, the estimated nutritive value was moderate, slightly lower

b)

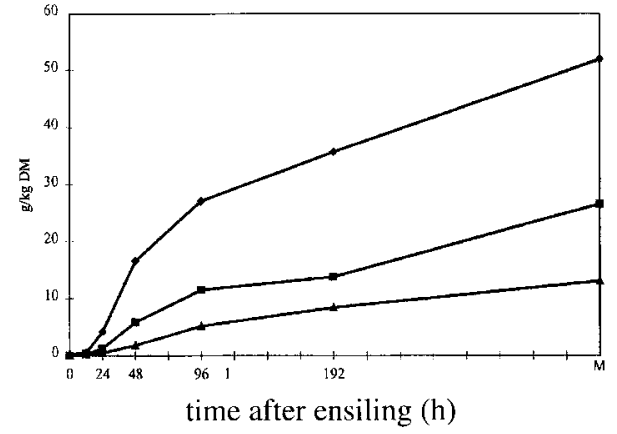

d)

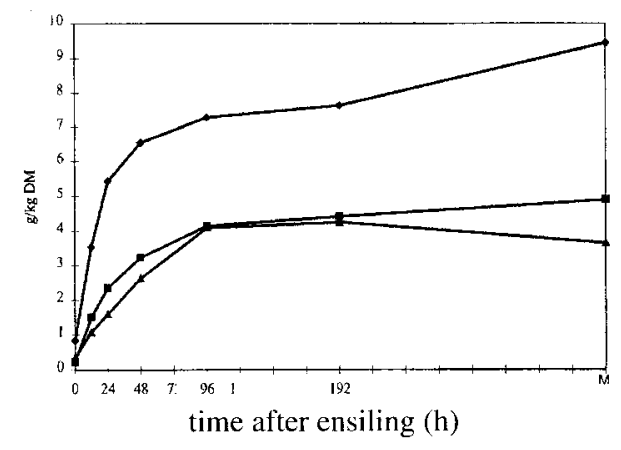

f)

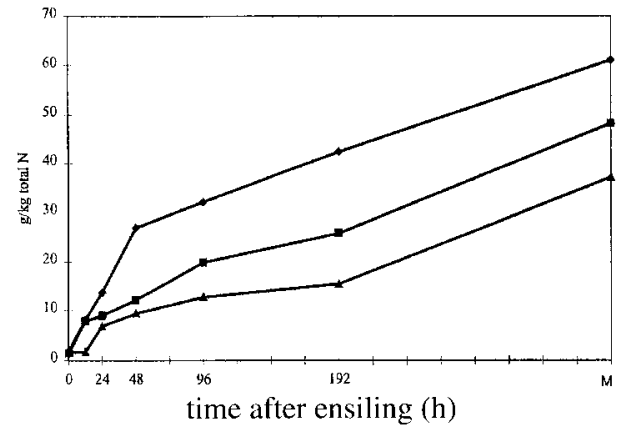

Figure 1. Changes in $\mathrm{pH}$ (a), lactic acid (b), acetic acid (c), ethanol (d), mannitol (e) and ammonia-N (f) until $192 \mathrm{~h}$ after ensiling in the S002 silos compared to mature silages (M) in the S500 silos $(\bullet \mathrm{T} 00 ; \boldsymbol{\square} 05 ; \boldsymbol{\Delta} \mathrm{T} 26)$. 
Table V. In vivo digestibility, voluntary feed intake and estimated nutritive value of the silages.

\begin{tabular}{|c|c|c|c|c|c|c|}
\hline \multirow[b]{2}{*}{ Wilting (h) } & \multicolumn{3}{|c|}{ Silages } & \multicolumn{3}{|c|}{ Significance ${ }^{1}$} \\
\hline & $\begin{array}{c}\text { T00 } \\
0\end{array}$ & $\begin{array}{c}\text { T05 } \\
5\end{array}$ & $\begin{array}{c}\text { T26 } \\
26\end{array}$ & s.e.d. & $L$ & $Q$ \\
\hline No. of ewes & 5 & 5 & 5 & & & \\
\hline \multicolumn{7}{|c|}{ Digestibility coefficients } \\
\hline $\mathrm{DM}$ & 0.52 & 0.55 & 0.58 & 0.02 & $* *$ & \\
\hline Organic matter & 0.53 & 0.56 & 0.58 & 0.02 & $* *$ & \\
\hline Crude protein & 0.33 & 0.42 & 0.44 & 0.04 & $*$ & \\
\hline NDF & 0.46 & 0.51 & 0.54 & 0.02 & $* *$ & \\
\hline Hemicellulose & 0.46 & 0.52 & 0.54 & 0.02 & $* *$ & \\
\hline $\mathrm{ADF}$ & 0.45 & 0.51 & 0.54 & 0.03 & $* *$ & \\
\hline Cellulose & 0.61 & 0.61 & 0.64 & 0.02 & & \\
\hline Energy & 0.49 & 0.53 & 0.54 & 0.02 & $*$ & \\
\hline \multicolumn{7}{|l|}{$D M$ voluntary intake } \\
\hline $\mathrm{g} / \mathrm{d}$ & 1060 & 1006 & 1090 & 135 & & \\
\hline $\mathrm{g} / \mathrm{kg} \mathrm{LW}^{0.75}$ & 47.2 & 44.5 & 48.2 & 4.8 & & \\
\hline \multicolumn{7}{|l|}{ Nutritive value } \\
\hline $\mathrm{DE}(\mathrm{MJ} / \mathrm{kg} \mathrm{DM})$ & 8.81 & 9.36 & 9.57 & & & \\
\hline $\mathrm{ME}(\mathrm{MJ} / \mathrm{kg} \mathrm{DM})$ & 7.18 & 7.60 & 7.74 & & & \\
\hline UFV (no./kg DM) & 0.46 & 0.50 & 0.52 & & & \\
\hline UFL (no./kg DM) & 0.56 & 0.60 & 0.61 & & & \\
\hline
\end{tabular}

${ }^{\mathrm{I}} L$, linear component of variance; $Q$, quadratic component.

than medium-quality hay. The voluntary intake of DM (47.2 g/day $/ \mathrm{kg} \mathrm{LW}^{0.75}$ ) was slightly higher than the restricted intake of the digestibility trial $\left(40 \mathrm{~g} /\right.$ day $\left./ \mathrm{kg} \mathrm{LW}^{0.75}\right)$.

Wilting significantly improved the apparent digestibility of DM (from 0.52 in T00 to 0.55 and 0.58 in T05 and T26 respectively, $P<0.01)$ and almost all nutrients. The estimated nutritive value was consequently higher in the wilted silages $(0.61$ UFL and $0.52 \mathrm{UFV} / \mathrm{kg}$ DM in T26 vs. $0.56 \mathrm{UFL}$ and 0.46 UFV in T00). The voluntary intake of wilted silages, on the other hand, was not significantly influenced by wilting.

Rumen fluid composition varied between the silages (table $V I$ ). As the length of wilting period increased, rumen fluid $\mathrm{pH}$ decreased significantly while total VFA concentration rose $(P<0.10)$. The rumen liquor of ewes fed wilted silages contained a slightly lower concentration of propionate $(P<0.05)$ and valerate $(P<0.01)$, while butyrate concentration was stimulated by wilting. The acetate: propionate ratio consequently increased slightly with wilting (from 3.13 to 3.21 , and $3.48 ; P<0.10$ ).

\section{DISCUSSION}

\subsection{Effect of wilting on chemical composition of grass}

Apart from DM concentration, in the present study there were very few changes in chemical composition caused by pre-wilting prior to ensiling. In fact, DM concentration of grass increased quickly and a slight decrease in its protein concentration was observed even after $26 \mathrm{~h}$. This decrease is 
Table VI. Molar proportions of volatile fatty acids in the rumen fluid of sheep 0 and $3 \mathrm{~h}$ after being fed the silages.

\begin{tabular}{|c|c|c|c|c|c|c|c|c|c|}
\hline & \multicolumn{4}{|c|}{ Wilting (W) } & \multicolumn{3}{|c|}{ Sampling time (S) } & \multicolumn{2}{|c|}{ Significance } \\
\hline & $\mathrm{T} 00$ & T05 & $\mathrm{T} 26$ & s.e.d. & $0 \mathrm{~h}$ & $3 \mathrm{~h}$ & s.e.d. & $W^{\prime}$ & $\mathrm{S}$ \\
\hline No. of samples & 10 & 10 & 10 & & 15 & 15 & & & \\
\hline $\mathrm{pH}$ & 6.99 & 6.85 & 6.68 & 0.10 & 7.02 & 6.66 & 0.08 & $* *$ & $* *$ \\
\hline Total VFA (mmol/L) & 57.9 & 65.8 & 63.3 & 4.3 & 53.1 & 71.6 & 3.5 & & $* *$ \\
\hline Acetate (\% total VFA) & 66.7 & 67.0 & 67.3 & 1.5 & 71.1 & 62.9 & 1.2 & & $* *$ \\
\hline Propionate (\% total VFA) & 22.0 & 21.3 & 19.9 & 1.0 & 19.0 & 23.1 & 0.8 & $*$ & $* *$ \\
\hline Butyrate ( $\%$ total VFA) & 8.4 & 9.5 & 10.6 & 0.8 & 7.9 & 11.1 & 0.6 & $* *$ & $* *$ \\
\hline Valerate (\% total VFA) & 2.9 & 2.3 & 2.2 & 0.2 & 2.1 & 3.0 & 0.1 & $* *$ & $* *$ \\
\hline Acetate:propionate ratio & 3.13 & 3.21 & 3.48 & 0.19 & 3.78 & 2.77 & 0.16 & $<0.10$ & $* *$ \\
\hline
\end{tabular}

' Linear component of variance.

likely to be due to mechanical losses (legume leaves). The rate herbage DM changes during wilting basically depend on weather conditions, while changes in chemical composition do not appear to be directly influenced by pre-wilting treatment $[10,14]$. Nevertheless, some authors observed that a long pre-wilting period can have a negative effect on the composition and ensiling suitability of herbage, especially when the weather is poor. This latter effect is due to the respiration and proteolytic processes that cause an appreciable reduction in water-soluble carbohydrates and an increase in ammonia- $\mathrm{N}$ concentration $[10,12]$. Kowalski et al. [11] and Yan et al. [28] found an appreciable increase in the protein concentration of wilted silages. In view of these possible effects, it is obviously preferable that wilting time prior to ensiling be as short as possible [19, 28].

\subsection{Effect of wilting on fermentation processes and ensiling losses}

Fermentative activity was considerably reduced by wilting, with changes during ensiling directly dependent on the variations of the initial herbage DM level.

Previous reviews of studies concerning the effect of wilting on silage quality showed a decrease in ammonia- $\mathrm{N}$ concentration in wilted silages [11]. Using unwilted (DM $206 \mathrm{~g} / \mathrm{kg}$ ), 24-h wilted (DM $346 \mathrm{~g} / \mathrm{kg}$ ) and 48-h wilted silages (DM $513 \mathrm{~g} / \mathrm{kg}$ ), inoculated or not with Lactobacillus plantarum, O'Kiely [17] observed an increase of ammonia- $\mathrm{N}$ production after $24 \mathrm{~h}$ of wilting (from 88 to $103 \mathrm{~g} / \mathrm{kg}$ total $\mathrm{N}$ ), followed by a decrease after $48 \mathrm{~h}(78 \mathrm{~g} / \mathrm{kg}$ total $\mathrm{N})$. Also, Charmley et al. [3] and Yan et al. [28] observed an increase in ammonia- $\mathrm{N}$ in some highmoisture harvests following wilting.

As regards the effect of initial moisture on the development of different bacteria involved in fermentation processes, our results demonstrated the virtual absence of clostridia activity in all silages (butyric acid $<1 \mathrm{~g} / \mathrm{kg} \mathrm{DM}$ ) and the reduction in lactic acid concentration was proportional to the increase of DM in the wilted silages but still sufficient to guarantee a suitable reduction in $\mathrm{pH}$. In fact, lactic acid bacteria appear to be less sensitive to increases in DM concentration than clostridia [12], which are virtually inhibited when the herbage DM is over $300 \mathrm{~g} / \mathrm{kg}$.

Some authors suggested that wilting can also modify the ratio between homofermentative and heterofermentative lactic species, but opinions on this subject vary widely. Muller et al. [16] observed the pre- 
valence of homolactic bacteria in respect to heterolactic strains, probably due to the different degree of osmotolerance. On the other hand, McDonald et al. [12] suggest that $98 \%$ of the lactic bacteria species in wilted silage are heterofermentative. The change in the homolactic index observed in our experiment seems to support the latter hypothesis.

On the whole, the high initial DM in all fresh herbages severely limited effluent and fermentation losses as these are appreciable only with initial DM less than $250 \mathrm{~g} / \mathrm{kg}[2,26]$.

Wilting reduced silage density, and this might increase respiration losses $[13,15]$. According to our results however, the decrease in fermentative activity amply compensates for the less favorable anaerobic conditions.

Results from the S002 mini-silos showed that fermentation processes differed significantly even only a few hours after ensiling. All the fermentation processes developed along similar pathways in the three silages but at lower intensities as wilting duration increased. Fermentation activity peaked between 24 and $96 \mathrm{~h}$ and then diminished. All these fermentation pathways lasted a minimum of $192 \mathrm{~h}$, even with progressively diminishing intensities and did not stop completely, as evidenced by the higher end-product levels reached in the mature silages. The differences between certain fermentation characteristics in the $\mathrm{S} 002$ silos opened after $192 \mathrm{~h}$, and the S500 silos opened after 6 months, could be ascribed not only to the slow fermentation process, but also to the different size and sealing system of the experimental silos $[25,26]$. Mannitol production was appreciable only after 2 days of ensiling and followed patterns already observed by other authors [13,27].

\subsection{Effect of wilting on digestibility, nutritive value and rumen fluid composition}

Unlike our results, many of the studies available $[3,6,19,21]$ demonstrated negative effects of wilting on the digestibility of silages by ruminants and ascribed them to the increase of nutrient losses in the field due to respiration.

In our trial no negative effect of wilting on field losses of nutrients was recorded, while the more intense fermentation activity of the unwilted silage could account for its lower nutritive value. In fact, if we calculate the concentration of indigestible protein in T00, T05 and T26, we find 55.6, 45.2 and $42.6 \mathrm{~g} / \mathrm{kg} \mathrm{DM}$, respectively. The value observed in T00 silage is unusually high, probably as a consequence of silage heating in the first phase of ensiling. This hypothesis is consistent with the evolution of fermentation processes we observed in the short term period.

Gordon and Peoples [7] reported lower nutrient digestibility in lactating cows fed silages cut from perennial ryegrass swards wilted under difficult weather conditions than unwilted silages, but an opposite tendency was observed in a similar experiment when wilting was achieved under sunny conditions [20]. Yan et al. [28] observed both positive and negative effects of wilting on the digestibility of perennial ryegrass silage depending on the harvest period. Both weather conditions and initial herbage DM, as in our trial, may modify the final DM after wilting with a positive effect on the conservation processes and therefore the nutritive value of silage.

As regards the voluntary intake of DM, the absence of difference between unwilted and wilted silages observed in our study contrast with observations made by other authors $[5,8]$ who reported a higher DM intake with wilted silages. However, in spite of the higher intake with wilted silage, this is often accompanied by a worsening of the overall animal performance [6, 21]. According to Patterson et al. [19], the decrease in the performance of animals fed wilted forages may depend on wilting management, since the longer the forage stays in the field, the higher the nutrient losses.

In our study, the variation in rumen fluid composition may partially explain the higher nutritive value calculated for wilted silages, 
which stimulated higher butyrate concentrations than unwilted silages. Similar observations were made by Peoples and Gordon [20] using silages wilted under favorable conditions, while Gordon and Peoples [7] did not find different rumen VFA concentrations in heifers fed silages from perennial ryegrass wilted under difficult conditions. In the rumen fluid of steers fed unwilted silages enriched with formic acid, O'Kiely and Flynn [18] found a lower acetate: propionate ratio than in steers fed wilted silages.

This study confirmed wilting as a preensiling treatment which is capable of improving the chemical characteristic of silages by reducing fermentation activity, proteolysis and storage losses even when the grass is harvested at a late stage of maturity (DM $300 \mathrm{~g} / \mathrm{kg}$ ). Ensiling after wilting appears to be a useful practice that should be applied in mountain areas, where the nutritive value of the permanent meadow grass is normally low and negatively affected by unfavorable weather conditions during haymaking.

Under these conditions, a short pre-wilting period improved the nutritional properties of the silages, since digestibility and hence nutritive value were observed to be significantly higher in wilted than unwilted silages. Better results were achieved when the wilting was extended for $26 \mathrm{~h}$ instead of $5 \mathrm{~h}$.

In contrast with some previous studies that documented a reduction in nutritive value in wilted silages, our results probably derive from the sunny weather during wilting and the high initial DM of herbage. These conditions contributed to a very rapid achievement of the moisture levels suitable for the correct evolution and orientation of the fermentation processes, by reducing the heating of the silage, and the improvement of nutrient utilization in some way. However, these observations should be further investigated by testing the effect of wilting on permanent meadow grass harvested at different stages of maturity.

\section{ACKNOWLEDGMENTS}

This research was funded by grants from CNR-RAISA. The authors thanks the Director of experimental farm of E.S.A.V. (Vallorch, Belluno), Dr. Paolo Quaia, for his collaboration and technical support during herbage harvest and silo preparation.

\section{REFERENCES}

[1] Associazione Scientifica di Produzione Animale (A.S.P.A.)-Commissione Valutazione Alimenti, Valutazione degli alimenti di interesse zootecnico. 2. Aspetti metodologici della digeribilità in vivo, Zoot. Nutr. Anim. 8 (1982) 387-394.

[2] Bastiman B., Altman J.F.B., Losses at various stages in silage making, Res. Dev. Agric. 2 (1985) 19-25.

[3] Charmley E., Gill M., Thomas C., The effect of formic acid treatment and the duration of the wilting period on the digestion of silage by young steers, Anim. Prod. 51 (1990) 497-504.

[4] Dulphy J.P., Demarquilly C., Problèmes particuliers aux ensilages, in : Demarquilly C. (Ed.), Prévision de la valeur nutritive des aliments des ruminants, Inra, Versailles, 1981, pp. 81-104.

[5] Forbes J.M., Voluntary food intake and diet selection in farm animals, CAB International, Wallingford, Oxon, OX10 8DE, UK, 1995, 532 p.

[6] Gordon F.J., Effect of silage additives and wilting on animal performance, in: Haresign W., Cole D.J.A. (Eds.), Recent advances in animal nutrition, Butterworths, London, 1989 , pp. 159-173.

[7] Gordon F.J., Peoples A.C., The utilization of wilted and unwilted silages by lactating cows and the influence of changes in protein and energy concentration of the supplement offered, Anim. Prod. 43 (1986) 355-366.

[8] Harrison J.H., Blauwiekel R., Stokes M.R., Symposium: utilization of grass silage, J. Dairy Sci. 77 ( 1994) 3209-3235.

[9] Harvey W.R., LSMLMW-PC2 Version. Mixed model. Least-squares and maximum likelihood computer program, Department of Dairy Science, Ohio State University, Columbus, Ohio 43210, USA, 1990.

[10] Henderson N., Silage additives, Anim. Feed. Sci. Techn. 45 (1993) 35-56.

[11] Kowalski Z.M., Pys J.B., Kanski J., The effect of cut, stage of growth and wilting on nitrogenous compounds and protein solubility in grass silages, J. Anim. Feed. Sci. 1 (1993) 213-221.

[12] McDonald P., Henderson A.R., Heron S.J.E., The biochemistry of silage, 2 nd edn, Chalcombe Publications, Marlow, UK, 1991, 340 p. 
[13] McDonald P., Henderson A.R., MacGregor A.W., Chemical changes and losses during the ensilage of wilted grass, J. Sci. Food. Agric, 19 (1968) 125-132.

[14] Messman M.A., Weiss W.P., Koch M.E., Changes in total and individual proteins during drying, ensiling, and ruminal fermentation of forages, J. Dairy Sci. 77 (1994) 492-500.

[15] Muck R.E., Factors influencing silage quality and their implication for managment, J. Dairy Sci. 71 (1988) 2992-3002.

[16] Muller M., Muller Y., Seyfarth W., Changes in the microbial epiphytic flora during wilting of fodder grasses and possible effects on ensiling, Agribiol. Res. 46 (1993) 28-39.

[17] O'Kiely P., Effect of adding a Lactobacillus plantarum inoculant to grass ensiled at different dry matter concentrations and offered to beef cattle, Anim. Sci. 58 (1994) 456A (abstract).

[18] O'Kiely P., Flynn A.V., Effect of wilting on the feeding value of grass silage for beef cattle, $J$. Anim. Sci. 63 (Suppl. 1) 288 (CAB Abstract 1984-1986).

[19] Patterson D.C., Yan T., Gordon F.J., The effect of wilting of grass prior to ensiling on the response to bacterial inoculation. 2. Intake and performance by dairy cattle over three harvests, Anim. Sci. 62 (1996) 419-429.

[20] Peoples A.C., Gordon F.J., The influence of wilting and season of silage harvest and the fat and protein concentration of the supplement on milk production and food utilization by lactating cattle, Anim. Prod. 48 (1989) 305-317.

[21] Thomas C., Thomas P.C., Factors affecting the nutritive value of grass silages, in: Haresign W., Cole D.J.A. (Eds.), Recent advances in animal nutrition, Butterworths, London, 1985 , pp. 223-251.
[22] Van Soest P.J., Nutritional ecology of the ruminant, O\&B Books, Inc., Corvallis, Oregon, 1982 , pp. 260-263.

[23] Vanbelle M., Bertin G., L'ensilage. Aspects biologiques nouveaux, Sanofi Santé Animale, Paris, 1985, pp. 75-79.

[24] Vermorel M., Nutrition énérgetique, in : Jarrige, R. (Éds), Alimentation des bovins, ovins et caprins, Institut National de la Recherche Agronomique, Inra, Paris, 1988, pp. 57-74.

[25] Xiccato G., Cinetto M., Rioni Volpato M., Studio dei processi di insilamento di foraggi mediante sili sperimentali. 1. Insilamento di trinciato integrale di mais e pomodori, Zoot. Nutr. Anim. 16 (1990) 309-322.

[26] Xiccato G., Cinetto M., Carazzolo A., Cossu M.E., The effect of silo type and DM content on the maize silage fermentation process and ensiling loss, Anim. Feed. Sci. Technol. 49 (1994) 311-323.

[27] Xiccato G., Parigi Bini R., Carazzolo A., Dalle Zotte A., Cossu M.E., Evoluzione dei processi fermentativi nell'erba di prato stabile montano insilata con polpe secche di bietola in sili sperimentali, in: XXVIII Simposio Internazionale di Zootecnia, Milan, 14 May 1993, Società Italiana per il Progresso della Zootecnia, Milan, 1993, pp. 495-506.

[28] Yan T., Patterson D.C., Gordon F.J., Porter M.G., The effect of wilting of grass prior to ensiling on the response to bacterial inoculation. 1. Silage fermentation and nutrient utilization over three harvests, Anim. Sci. 62 (1996) 405-417. 